Article

\title{
Eroticizing Marx, Revolutionizing Freud: Marcuse's Psychoanalytic Turn
}

Jeffry V. Ocay

$\mathrm{T}$ The conclusion arrived at in the article titled "Heidegger, Hegel, Marx: Marcuse and the Theory of Historicity," which appeared in a previous issue of this journal, accounts for Herbert Marcuse's view of the possibility of the individual to become disposed to radical action. ${ }^{1}$ Marcuse thus wants to suggest that there is still hope for the Enlightenment's project of "emancipation," and that there is still a revolutionary subject who can carry out this political struggle for liberation. The progression of consciousness which results in a historically conscious individual exemplified by the "conscious slave" in Hegel's discussion of master-slave relation provided Marcuse the basis of his claim that the individual can be an active and dynamic political subject. Yet the slave who realizes via the notion of labor that it is himself and not the master who is truly free is, after all, still a slave. This means that individuals still need to fight for their freedom. ${ }^{2}$

Like Marx, Marcuse believes that the internal logic of overproduction and excessive consumption vis-à-vis massive pauperization ${ }^{3}$ in a capitalist society lead to the self-destruction of society. The capitalist system of overproduction coupled with excessive consumption creates insatiable individuals whose needs and desires are impossible to satisfy. ${ }^{4}$ This is dangerous for Marcuse because as the society produces more and more to

1 See Jeffry V. Ocay, "Heidegger, Hegel, Marx: Marcuse and the Theory of Historicity," in KRITIKE: An Online Journal of Philosophy, 2:2 (December 2008), 46-64, $<$ http://www.kritike.org/journal/issue_4/ocay_december2008.pdf $>$.

2 In Chapter IV of the Phenomenology, Hegel shows that the master-slave dialectic necessarily results in the consciousness of the slave, that is to say, the slave's realization that he is free. But for Hegel this notion of freedom is at first abstract, thus the slave continues to struggle for freedom. This process, Hegel argues, involves three stages or moments, namely: Stoicism, Skepticism, and Unhappy Consciousness. See G.W.F. Hegel, The Phenomenology of Mind, Translated with an introduction and notes by J.B. Baillie (Mineola, New York: Dover Publications, 2003), 104-130. For a detailed discussion of Hegel's master-slave dialectic, see Paolo Bolanos, "Hegel and the Pathologies of Freedom," in Cogito, 4:1 (2006), 37-43 and also Robert Sinnerbrink, "Recognitive Freedom: Hegel and the Problem of Recognition," in Critical Horizons, 5 (2004), 271-295.

${ }^{3}$ Marcuse believes that pauperization is one of the factors that sustain capitalism. In Counterrevolution and Revolt, Marcuse says that capitalism grows through growing pauperization. The burgeoning poverty and unemployment in both rich and underdeveloped countries is always a reality in a capitalist system. See Herbert Marcuse, Counterrevolution and Revolt (London: Allen Lane The Penguin Press, 1972), 16.

${ }^{4}$ Ibid. 
address the yearnings of such unquenchable individuals, a discrepancy between the purchasing power of the individuals and the volume of goods and services produced by the capitalist society would ensue at some point in time. Marcuse avers that this would cause the disintegration of the capitalist order. ${ }^{5}$ We might view the current financial crisis in this light. ${ }^{6}$ One can also reflect on how the Wall Street meltdown, which started with the collapse of Bear Stearns, Lehman Brothers and other key financial institutions in the United States, has profoundly affected the world economy. In fact, few months after the Wall Street meltdown, the European economy along with the Asian and Australian economies began to plunge. And what is interesting now is that these capitalist economies have resorted to some of the basic principles of socialism: the partial or full nationalization of the State's major industries. In the United States, the intervention of the government to rescue the American International Group (AIG) signals the transition from capitalism to socialism. With this, it appears that Marx's prediction that capitalism will self-destruct is beginning to dawn.

As we can observe, Marcuse was utterly convinced that "historicity" would necessarily engender a historically conscious individual who is disposed to radical action. This type of individual is for Marcuse the key factor of the transition from capitalism to socialism. But since the self-destruction of capitalism would not necessarily lead to socialism, it therefore needs a subject who can arrest the situation and appropriate it in order to realize socialism. This is precisely the role of the historically conscious individual who is disposed to radical action.

Contrary to what Marx predicted, however, Marcuse realized that the transition from capitalism to socialism did not happen. What happened instead were the integration of the proletariat into the status quo, the stabilization of capitalism, the bureaucratization of socialism (as in the case of the former Soviet Union), and the absence of a revolutionary agent for progressive social change. Marcuse saw that the capitalist society had developed a technique that effectively dissolves "opposition" in the society and reduces the individuals into acquiescence or even complicity. The result is obvious for Marcuse: a conformist society. ${ }^{7}$ This explains why Marcuse attempted to complement his revitalization of Marxism with Freud. Marcuse's attempt to revitalize Marxism through Heidegger and Hegel, therefore, does not suffice. It needs another decisive piece to complete the methodological puzzle: Freud's psychoanalysis.

${ }^{5}$ Marcuse, Counterrevolution and Revolt, 16.

6 The market's emphasis on credit and (over)spending has resulted in deflation wherein goods and services are still available in abundance but people reduce or desist spending because they can no longer pay their debts or they can no longer afford to avail these goods and services. Consequently, companies and financial institutions collapse in a domino effect. For example, a synchronized closures of department stores would lead to the closures of factories, then to the collapse of the mining industries, and then to other industries that help sustain this constellation.

${ }^{7}$ Marcuse later describes this society as "one-dimensional." 


\section{MARCUSE'S PSYCHOANALYTIC TURN}

This is the main thrust of this essay-an engagement on how Marcuse attempted to provide Marxism its anthropological basis by going into the depth dimension of the human psyche, by appropriating Freud's theory of instincts. Thus, an eroticized Marx and a revolutionized Freud ensued. Marcuse's intention here is clear: to explain why the transition from capitalism to socialism did not happen, why, especially in the 1930s, the revolutionary class had been dissolved and became conformist, and also how this conformism was even extended in the post-war era. ${ }^{8}$ In his engagement with Freud's theory of instincts, Marcuse also intends to explicate his second notion of liberation, an attempt which he vigorously grapples with throughout his lifetime. The discussion that follows centers on Marcuse's 1950s work, which he considers to be his magnum opus: Eros and Civilization.

Central to Freud's theory of instincts, as Marcuse reconstructs it, is the idea that there is an inherent antagonism between the satisfaction of human instincts and individual freedom on the one hand and the development of civilization on the other. For Freud, this antagonism is an antagonism between individual and cultural demands, or sexuality and civilization. ${ }^{9}$ And in order for civilization to thrive the demands of the human instincts must be constantly held in check by some socially useful norms. These normative standards and their repressive tendencies are considered a necessity. Freud sees this phenomenon as the humanization of the animal man. Based on the context of necessity, this process of humanization is considered as the progression of the human being. And since Freud supposes that the progression of the individual is virtually analogous to the progression of civilization, then the repression of the human instincts strengthens social bonds which necessarily results in the advancement of civilization - it brings progress in civilization and at the same time facilitates the smooth functioning of the entire system. The explanation Freud gave as to the necessity of this repressiveness in civilization is twofold, namely, biological and economic.

Firstly, Freud believes that civilization begins with the twofold systematic repression of the primary instincts of man, to wit: a) the repression of life-instincts (Eros), ensuing in durable and expanding group relations, and b) the repression of the destructive instincts (Thanatos), leading to the mastery of man and nature, to the individual and social morality. ${ }^{10}$ Eros, whose elemental goal is the preservation of life, and Thanatos, whose primary goal is the destruction of life, are the two mechanisms immanent within the human psyche that man uses in the process of releasing tension. ${ }^{11}$ Eros does it through

\footnotetext{
8 This is also the problem of Horkheimer, Adorno, Benjamin, and other early members of the Frankfurt School.

9 See Edward Hyman, "Eros and Freedom: The Critical Psychology of Herbert Marcuse," in Robert Pippin, Andrew Feenberg, Charles P. Webel, and Contributors, Marcuse: Critical Theory and the Promise of Utopia (Massachusetts: Bergin and Garve Publishers, 1988), 145.

10 Marcuse, Herbert Marcuse, Eros and Civilization: A Philosopbical Inquiry into Frend (United States of America: The Beacon Press, 1966), 95.

${ }^{11}$ Sigmund Freud, The Ego and the Id, Translated by Joan Riviere, Revised and Edited by James Strachey (New York and London: W.W. Norton and Company, 1962), 30.
} 
the immediate satisfaction of sexual desires, while Thanatos does it through destruction or death. Both Eros and Thanatos work under the pleasure principle. For Freud, this is the dynamics of life; life is a "conflict and compromise between these two trends." 12 Now, these two conflicting forces within man himself are basically brute forces. They are perilous and would cause destruction to man in particular and to civilization in general if left unchecked. According to Freud, a society where the demands of Eros and Thanatos receive immediate satisfaction is inconceivable. No rational society can ever have this system. People cannot just do whatever they want to do. Thus, man needs to restrain his destructive instincts by conforming to some socially useful norms. This is exactly the reason why Freud fully accepts the necessity and virtue of repression. Eros and Thanatos which work under the pleasure principle must succumb to the rule of the reality principle, the general guideline along which the organism develops and preserves itself in the face of the restraining environment. ${ }^{13}$ Freud vehemently argues: "Civilization has to use its utmost efforts in order to set limits to man's aggressive instincts and to hold the manifestation of them in check by physical reaction-formation."'14

Secondly, Freud also believes that the repression of the human instincts is enforced and sustained by scarcity or Ananke, ${ }^{15}$ which, according to Edward Hyman, is the underlying principle of the reality principle. ${ }^{16}$ Ananke forces man to work in order to survive, in order to put food on the table. And since the society in the past "...has not means enough to support the life of its members without work on their part, it must see to it that the number of these members is restricted and their energies directed away from sexual activities on to their work." 17 In his engagement with Marcuse's Eros and Civilization, Barry Katz puts it aptly:

Chief among the environmental variables that condition the prevailing repressive organization of the instincts is the brute fact of material need, Ananke: the condition of scarcity that has dominated the world history of civilized society has dictated that a considerable part of the instinctual (libidinal) endowment of the population be diverted from enjoyment into productive labor. ${ }^{18}$

\footnotetext{
12 Ibid., 31.

13 John Fry, Marcuse - Dilemma and Liberation: A Critical Analysis (New Jersey: Humanities Press, 1978), 41.

14 Sigmund Freud, Civilization and Its Discontents, Edited by M. Masud R. Khan, Translated by James Strachey (London: The Hogarth Press and the Institute of Psycho-Analysis, 1973), 49.

${ }^{15}$ Marcuse, Eros and Civilization, 32.

${ }^{16}$ See Hyman, "Eros and Freedom," 152.

${ }^{17}$ Ibid., 32-33. But in the advanced industrial society, Ananke is no longer a problem. This will be tackled later.

18 Barry Katz, Herbert Marcuse and the Art of Liberation: An Intellectual Biography (London: Verso, 1982), 150.
} 


\section{MARCUSE'S PSYCHOANALYTIC TURN}

"Work," for Freud, is one of the foundations (the other is Eros) of society. ${ }^{19}$ Freud says that men "come together," i.e., live in society, first because they are forced to do so by economic necessity (Ananke) and second because they want to do so to acquire their sexual objects (Eros). In fact, for Freud, as for Marcuse, civilization is first of all progress in work-that is, work for the procurement and augmentation of the necessities (Ananke) of life. ${ }^{20}$ This work is of necessity in opposition to erotic instincts, and so a repression of libido, because a direct libidinal fulfilment comes in the way of efficient work. Michael H. Lessnoff observes that Freud's theory of instincts suggests that the pleasure-seeking instincts must give way to non-libidinal work. ${ }^{21}$ In the same vein, C. Fred Alford observes that Marcuse interprets Freud's theory of instincts in this way: "Culture demands the sublimation of the erotic drives so that the psychic energy that would otherwise be directed toward immediate gratification should be inhibited in its aim and rechanneled into work." 22 This gives us the impression that erotic impulses can provide the source of the energy that is "redirected" in work. This also gives us a much more precise image of the repression demanded by Ananke: not destruction of instincts, but rechanneling.

The repression of the human instincts by some socially useful norms is precisely what is meant by the inhibition of the pleasure principle by the reality principle. To see now how this dialectic of pleasure and reality principle plays out in the formation of a subject, let us discuss briefly Freud's account of the opposition between the "pleasure principle" and "reality principle" and the "ego" and the "id."

First, the pleasure principle is the governing principle of the id; the id is that part of the human psyche which is entirely unconscious. On the other, the reality principle is the governing principle of the ego; the ego is part of the id but has been modified due to its direct contact with the external world.23 Freud claims that the ego represents reason and common sense, while the id represents passion. ${ }^{24}$ Now, the instincts of the id, being governed by the

19 Freud puts it clearly in his seminal work Civilization and Its Discontents: "The communal life of human beings had, therefore, a two-fold foundation: the compulsion to work which was created by external necessity (Ananke), and the power of love (Eros), which made the man unwilling to be deprived of his sexual object...." See Freud, Civilization and Its Discontents, 38. Emphasis added.

${ }^{20}$ Marcuse, Eros and Civilization, 77.

21 See Michael H. Lessnoff, Political Philosophers of the Twentieth Century (Oxford: Blackwell Publishers, 1999), 53.

22 C. Fred Alfrod, Science and the Revenge of Nature, Marcus and Habermas (Florida: University Presses of Florida, 1985), 38-39. Emphasis added.

${ }^{23}$ We may notice here that Freud is quite inconsistent about his theory of the human psyche. He said that the id is entirely unconscious, but at some point, he said that the ego is part of the id. Nonetheless, and I suppose, what Freud is saying is that from the very beginning, the id is indeed entirely unconscious, but once it has come in contact with the external world, part of it becomes the ego.

${ }^{24}$ Freud, Ego and the Id, 15. 
pleasure principle, press for immediate satisfaction at all costs. ${ }^{25}$ This is the nature of the id. It seeks to satisfy whatever it wants without considering the possible danger. It is at this point, therefore, that the ego comes to the rescue. As the conscious part of the id, the ego mediates between the demands of the id and the external world. ${ }^{26}$ (The superego is discussed in the later part.) The ego then observes the external world through the senses and captures those moments of harmless satisfaction and then imposes it upon the id. In this way, the id is bridled by way of delaying its satisfaction or even modifying its aim. This is precisely what Freud calls "sublimation" of the instincts. ${ }^{27}$ When this happens, the inhibition of the pleasure principle by the reality principle becomes complete.

The complete inhibition of the pleasure principle by the reality principle does not suggest that the yearning for pleasure is completely abandoned. It is only postponed for the sake of a long-lasting and more secure pleasure in the future. As Freud says in Beyond the Pleasure Principle, the postponement of satisfaction is only a step on the long, indirect road to pleasure. ${ }^{28}$ This renunciation of instinctual satisfaction is characterized by momentary absence of pleasure and a coming back of the object of pleasure. ${ }^{29}$ Inasmuch as there is a coming back of the object of pleasure, it can be inferred that there is a "pleasurable" ending in this process. However, we must be cautious so as not to be led to believe that in the end happiness is attained, for Freud insists tenaciously that happiness is impossible. Civilization, in the end, categorically implies "control and domination," the sheer denial of human freedom and happiness. As a matter of fact, Freud believes that life is basically suffering and that the dynamics of nature proves this point. He said there is no possibility at all that happiness can be achieved since all regulations of the universe militate against it. Freud writes:

We are threatened with suffering from three directions: from our own body, which is doomed to decay and dissolution and which cannot even do without pain and anxiety as warning signals; from the external world, which may rage against us with overwhelming and merciless

\footnotetext{
${ }^{25}$ Sigmund Freud, Two Short Accounts of Psycho-Analysis, Translated and Edited by James Strachey (London: Penguin Books, 1991), 111.

${ }^{26}$ Ibid. Cf. Plato's psychology. In Platonic psychology, man is viewed as a being who is composed of three kinds of souls, that is, the rational soul, spiritual soul, and the appetitive soul. Each has its specific location in the human body. The rational soul is located in the head, the spiritual soul in the chest, and the appetitive in the abdomen. For Plato, the rational soul must rule over the spiritual and the appetitive souls to attain a well-balanced personality. This is because the spiritual and appetitive souls are irrational, hence if left untamed would cause destruction of the individual. See Eddie R. Babor, The Human Person: Not Real, But Existing (Manila: C \& E Publishing, 2001), 55-57.

27 See Freud, Two Short Accounts, 111.

${ }^{28}$ Sigmund Freud, Beyond the Pleasure Principle, Translated and Edited by James Strachey, Introduction by Gregory Zilboorg, with Biographical Introduction by Peter Gay (New York and London: W.W. Norton and Company, 1961), 7.

${ }^{29}$ Ibid., $13-15$
} 


\section{MARCUSE'S PSYCHOANALYTIC TURN}

forces of destruction; and finally from our relation to other men. The suffering which comes from this last source is perhaps more painful than any other. ${ }^{30}$

In regard to the first two sources, our judgment cannot hesitate long. It forces us to acknowledge those sources of suffering and to submit to the inevitable. We shall never completely master nature; and our bodily organism itself a part of that nature, will always remain a transient structure with a limited capacity for adaptation and achievement. ${ }^{31}$

As regards the third, the social source of suffering...we do not admit it at all; we cannot see why the regulations made by ourselves should not, on the contrary, be a protection and a benefit for every one of us. ${ }^{32}$

But what Freud wants to elucidate at this point is not only the fact that man is destined to suffer, but also the cause which gives rise to this sufferingsuffering is a direct upshot of the repression of instincts. And what is interesting here as we have seen is that Freud never repudiates this repression. On the contrary, he argues that it is necessary in order to preserve life. Freud appears here a cheerful pessimist. Although he is completely sold on to the idea that happiness is too good to be true, Freud still insists that man needs to struggle for the preservation of life, for the preservation of civilization. And, again, this can be done through the repression of instincts. Therefore, momentary pleasure, which bespeaks of the oscillation of pleasure and unpleasure in life, is the least that man can ever have. It characterizes what Freud maintains that the antagonism between the pleasure principle and the reality principle is eternal.

There is still one final question that needs to be addressed. In Civilization and Its Discontents, Freud asks the questions: "What means does civilization employ in order to inhibit the aggressiveness (of the human instincts) which opposes it, to make it harmless, to get rid of it, perhaps?"33 Let us deal with this query before discussing Marcuse's engagement with Freud.

Freud maintains that these aggressive and brute forces in man can be tamed through the institution of the "superego" and "conscience." If the ego is the conscious part of the id, the superego is the moral component of the ego that precipitates after the ego's first contact with objects. In The Question of Lay Analysis: An Introduction to Psychoanalysis, Freud stipulates that the superego is a special agency of the ego, which turns against the ego and at the same time

\footnotetext{
${ }^{30}$ Freud, Civilization and Its Discontents, 13.

${ }^{31}$ Ibid., 23.

32 Ibid.

${ }^{33}$ Freud, Civilization and Its Discontents, 60. Emphasis added.
} 
imposes upon it a kind of moralistic rule: conscience. ${ }^{34}$ The superego, therefore, as an agency of the ego, is that specific agency in the human psyche that appropriates the reality principle of the external reality and then exacts control over the id, the seat of the pleasure principle. The superego (reality principle) and the id (pleasure principle) are mediated by the ego. In Freud's analysis, the ego is sandwiched between the id and the superego, but it plays the significant role of exacting a balance between the selfish demands of the id and the imposition of the moralistic rule of the superego. When overburdened by its tasks, the ego exerts defense mechanisms such as denial and repression. Conscience, through the superego, because for Freud the superego is the vehicle of conscience, watches over the ego's actions and intentions and exercises censorship on them. ${ }^{35}$ In this manner, the aggressive instincts in man are being weakened or disarmed resulting in a well-balanced personality and a well-functioning society. But this requires first of all an unconditional submission of the ego to the superego. This makes Freud argue that any form of perversion must be tabooed. He believes that perversion is not only detestable but also something monstrous and terrifying. ${ }^{36}$ This is because perversion is an expression of rebellion of the pleasure principle against the reality principle which subjugates the aggressive and brute forces in man (Eros and Thanatos), a subjugation which, as argued earlier, brings progress in civilization and facilitates the smooth functioning of the entire system. It is now not hard for us to see why Freud vehemently insists that the human instincts must be repressed at all costs.

What results in this process is the "sense of guilt," the perception which the ego has after being watched over by the superego. ${ }^{37}$ Now, Freud is convinced that this is how civilization ought to be, that the aggressive instincts should always be held in check and that the sense of guilt must be permanent or even heightened. Every little advance in civilization should carry along with it a proportionate degree of guilt. For Freud, this is the price of civilization. If this is the case, then how else can man attain happiness?

In contradiction to Freud's claim that man cannot live under the pleasure principle, that happiness cannot be attained, Marcuse believes the goal of life is not merely security but pleasure, and, hence, the struggle for existence is originally the struggle for pleasure. ${ }^{38}$ Thus, Marcuse avers that a nonrepressive society, that is, free and happy society, is viable. The antagonism between the sexual instincts and the restrictions of civilization is sociohistorical and, therefore, avoidable. In other words, such antagonism is simply a product of the historical human organization in society and, therefore, is subject to change. For Marcuse, the subjection of the pleasure principle to the

34 Sigmund Freud, The Question of Lay Analysis: An Introduction to Psychoanalysis, Translated by Nancy Procter-Gregg, with Foreword by Ernest Jones (London: Imago Publishing Company, 1947), 48.

${ }^{35}$ Freud, Civilization and Its Discontents, 73.

${ }_{36}$ Marcuse, Eros and Civilization, 53.

${ }^{37}$ Freud, Civilization and Its Discontents, 73.

${ }^{38}$ Marcuse, Eros and Civilization, 106. 


\section{MARCUSE'S PSYCHOANALYTIC TURN}

reality principle is due not primarily to nature but to man, to the administrators of the society.

It is important to note that the purpose of Marcuse's engagement with Freudian theory is not so much to criticize the defects (as Marcuse perceived it to be) of Freud's thoughts. Nor Marcuse is concerned about the epistemological aspect of Freud's theory of instincts. As has been pointed out in the early part of this section, Marcuse's cardinal purpose in appropriating Freud's theory of instincts is to provide the anthropological basis of Marxism. What concerns Marcuse in Freud's theory of instincts then is its potential revolutionary character. Marcuse believes that it is an explosive theory because the release of Eros from subjection under the reality principle would categorically result in a "complete human being." 39 According to Marcuse, the inherent antagonism between Eros and Thanatos and their opposition to the external reality point to the possibility of liberation. This makes Marcuse argue that the basic concepts of Freudian theory do not need dismantling, but rather pressing them to the limits. ${ }^{40}$ Barry Katz argues that this "pressing to the limits" of Freudian metapsychology is intimately linked to Marcuse's constant attempt to ground the historicity of human action. This passage from Freudian psychology to a theory of historicity occurs via mediating concepts, borrowed from Benjamin, like "remembrance" or "recollection."41 According to Katz, Freud's theory of instincts provided the content and context of Marcuse's notion of remembrance: what is to be remembered now is the primal stage of polymorphous gratification which has its origin in infancy. ${ }^{42}$ This is because for Marcuse, as Kats observes, the unconscious instincts preserve the memory of the past stages of individual development at which integral gratification is obtained. ${ }^{43}$

But because Freud failed to distinguish adequately between the biological and socio-historical vicissitudes of the instincts, that is, between their biologically given nature and the shape they take in distinctive historical periods and social set-ups, he had defused an explosive theory. ${ }^{44}$ Marcuse attempts to reactivate such explosive theory by unravelling the socio-historical aspect of the instincts. To do this, Marcuse introduces two key concepts: surplus repression and performance principle. Marcuse employs these concepts to argue that human history can be divided into two phases: first, which has lasted until the modern age, social domination (or basic repression) was necessary to remove scarcity and lay the technological foundations for abundance, and; second, the advancement of science and technology, which has successfully answered the problem of material necessity, has rendered

\footnotetext{
${ }^{39}$ See Peter Lind, Marcuse and Freedom (London and Sydney: Croom Helm, 1985), 194.

${ }^{40}$ Katz, Herbert Marcuse, 147-150.

${ }^{41}$ Ibid., 153.

42 Ibid., 154

${ }^{43}$ Ibid., 153.

${ }^{44}$ Ibid., 49.
} 
repression needless. ${ }^{45}$ On the one hand, surplus repression is one which is necessitated by social domination; it is an additional control which arises from the specific institution of domination. ${ }^{46}$ Marcuse borrows this notion from Marx's surplus value. In Marx, for the surplus value to be extracted from labor power, corresponding social structures must be in place which ensure that a surplus of repression prevents workers from rejecting the extra effort demanded of them and indeed forces them to accept these extra efforts. Morton Schoolman actually shows that surplus repression can also be understood as a specific organization of scarcity through the creation of artificially manufactured needs. ${ }^{47}$ Since scarcity is in theory overcome with modern production, there is no longer a need for any repression. In theory, we could let machines do the work for us. We now live under a new reality principle, with a decisive weakening of the Ananke. This is where Marcuse's key notion of "performance principle" plays its central role. According to Marcuse, the performance principle is the historical form of the reality principle. ${ }^{48}$ If in Freudian theory it is the reality principle that demands repression, for Marcuse, it is now the performance principle in the guise of reality. ${ }^{49}$ Marcuse justifies his position by claiming that the advancement of science and technology had already put an end to Ananke, that is, to the reality principle. Marcuse argues: "The issue of scarcity which legitimizes the repression in previous civilizations seems to be untenable now. In the advanced industrial society, the procurement of basic needs is no longer a problem, but it is the manner in which these material needs are distributed and utilized." 50 It seems that this is now the moment that work can be eroticized, that men no longer need to work long and hard but work less and enjoy more. However, the capitalist system of (over)production and lavish, and seemingly unlimited, consumption has maintained the prevalence of the reality principle through the creation and valorization of artificial needs. ${ }^{51}$ In his reading of Marcuse's Eros and Civilization, Richard Kearney observes that the performance principle which governs the capitalist society manipulates instinctual desires through the invention of new (unnecessary) needs as soon as the old (necessary) ones are satisfied. ${ }^{52}$

The manipulation of the instincts results not only in "surplus repression" but also in the eventual release of Thanatos from control under Eros. 53 This loosening up of Thanatos under the dominion of Eros can be seen

\footnotetext{
45 See Alasdair MacIntyre, Herbert Marcuse: An Exposition and a Polemic (New York: The Viking Press, 1970), 49

${ }^{46}$ Marcuse, Eros and Civilization, 44.

${ }^{47}$ Morton Schoolman, The Imaginary Witness: The Critical Theory of Herbert Marcuse (New York: The Free Press, 1980), 95.

48 Marcuse, Eros and Civilization, 44.

${ }^{49}$ MacIntyre, Herbert Marcuse, 49.

${ }^{50}$ Marcuse, Eros and Civilization, 84.

51 See Schoolman, The Imaginary Witness, 95.

52 Richard Kearney, Modern Movements in European Philosophy, Second Edition (Manchester and New York: Manchester University Press, 1994), 214.

${ }^{53}$ Ibid.
} 


\section{MARCUSE'S PSYCHOANALYTIC TURN}

in the First and the Second World Wars, the Holocaust, the Cold War, and other events that suggest destruction.

The institutionalization of surplus repression through the performance principle is made possible by "repressive desublimation," a Marcusean theory which bespeaks of the process of "mass repression whereby consumers came to identify libidinally with the commodities they purchased." 54 Here, "the demands of the life-instincts originally characterized by polymorphous sexuality, are permitted expression and gratification in safe (or even useful) form of activity." 55 Thus, the demands of the sexual instincts meet fewer taboos and, this is crucial, liberated instincts can be redirected towards productive goals, rather than expand for themselves. Liberation from repression, instead of being synonymous with liberation of the human being, in fact leads to greater subservience to the economic order and its productivist and consumerist logics. As John Fry has shown, this results in the eroticization of the originally non-erotic objects, e.g., cars, clothing, houses, gadgets, and the likes. ${ }^{56}$

Marcuse's theory of "repressive desublimation" has indeed brought reification of consciousness to qualitatively new heights. Domination continues, even rigidified, in the midst of apparent liberation. This initially explains why the revolutionary class has been dissolved and became the very instrument that perpetuates domination, and why the anticipated selfdestruction of capitalism did not happen.

Since the performance principle and surplus repression of the capitalist society make work unpleasurable and breed ersatz individuals with pseudo freedom, Marcuse then calls for a new type of individuals who do not repress their sensuous erotic desires but cultivate them instead. ${ }^{57}$ Cynthia Willet shows very well that the fundamental thesis of Marcuse's Eros and Civilization is the invocation of the highest type of individuals who pursue a life devoted to "pleasure." 58 These are the liberated individuals - the type of individuals with the new sensibility. They are the individuals who transform work into play, who eroticize work. And, contrary to Freud's stance that individuals must postpone the gratification of their instincts, for Marcuse, the liberated individuals are those who celebrate the immediate gratification of the "senses" since Ananke no longer holds sway over human beings. In this way, the human body (because Marcuse's notion of the "senses" refers to the entirety of the human body) is no longer arrested by the performance principle. The human body ceases to be an instrument of alienated labor. It is no longer haunted by conscience and the sense of guilt, but becomes the vehicle of

\footnotetext{
${ }^{54}$ Richard Wolin, Heidegger's Children, Hannah Arendt, Karl Lowith, Hans Jonas, and Herbert Marcuse (Princeton and Oxford: Princeton University Press, 2001), 168.

${ }^{55}$ Fry, Marcuse-Dilemma and Liberation, 41.

${ }^{56}$ Ibid.

${ }^{57}$ See Cynthia Willet, "A Dialectic of Eros and Freedom: Beauvoir and Marcuse," in Between the Psyche and the Social: Psychoanalytic Social Theory, Edited by Kelly Oliver and Steve Edwin (New York: Rowan and Littlefield Publishers, 2002), 205.

${ }^{58}$ Ibid., 207.
} 
liberation. ${ }^{59}$ For Marcuse, this is the road to the realization of a non-repressive, free, and happy society that Freud completely dismissed.

Finally, the notion of "perversion," which is tabooed in Freudian theory, becomes for Marcuse a form of "refusal" against the system of control and domination exacted by the (capitalist) society. Marcuse views perversion as an expression of rebellion against the subjugation of sexuality. ${ }^{60}$ It is the revolt of the pleasure principle against the performance principle. ${ }^{61}$ In Eros and Civilization, Marcuse argues that the most liberating form of perversion is "phantasy" because it "continues to speak of the language of the pleasure principle, of freedom from repression, of uninhibited desire and gratification." 62 Hence, it envisions a world that is free from control and domination. In other words, it is phantasy that projects the image of a nonrepressive, free, and happy society. In relation to Marcuse's theory of "remembrance," it is phantasy that remembers or recollects those moments of instinctual gratification in the past, which for Marcuse is the image of liberation tabooed by the prevailing rationality. Inasmuch as Marcuse's notion of liberation involves the recollection of the forgotten image of liberation, inasmuch as this oblivion is due primarily to the complete inhibition of the human instincts (pleasure principle) by the performance principle (reality principle for Freud) via the institutionalization of surplus repression, and inasmuch as it is phantasy that can recollect this forgotten image of liberation, then it logically follows that in the end it is the power of phantasy that can practicably bring the project of emancipation into fruition.

One more remark deserves mention here. For Marcuse the rebellious power of phantasy occurs in "art" because the projection of a non-repressive, free, and happy society is basically a projection of the aesthetic dimension, of the beautiful. Art in this way is understood as a form of critique. In the Aesthetic Dimension, Marcuse argues that art protests and at the same time transcends the system of domination. ${ }^{63}$ In One-Dimensional Man, he shows that art assumes a political role; he said that art could invalidate and transform the existing pathological society. ${ }^{64}$ Put differently, art points to forms of social pathologies and then offers the alternative. This being the case, art, therefore, is a decisive factor in the struggle for emancipation.

Department of Philosophy, Siliman University, Philippines Department of Philosophy, Macquarie University, Australia

${ }^{59}$ In Eros and Civilization Marcuse employs the images of the Greek gods Orpheus and Narcissus to portray the image of a liberated individual. This is explained fully in the next section titled "Technology, Technological Domination, and the Great Refusal."

${ }^{60}$ Marcuse, Eros and Civilization, 53.

${ }^{61}$ Ibid., 54.

62 Ibid., 120.

${ }^{63}$ Herbert Marcuse, The Aesthetic Dimension: Toward a Critique of Marxist Aesthetics (London: The Macmillan Press, 1979), ix.

${ }^{64}$ Herbert Marcuse, One-Dimensional Man (Boston: Beacon Press Boston, 1964), 238. 


\section{MARCUSE'S PSYCHOANALYTIC TURN}

\section{References}

Alford, C, Fred, Science and the Revenge of Nature, Marcus and Habermas (Florida: University Presses of Florida, 1985).

Babor, Eddie R,, The Human Person: Not Real, But Existing (Manila: C \& E Publishing, 2001).

Bolanos, Paolo, "Hegel and the Pathologies of Freedom," in Cogito, 4:1 (2006), 37-43.

Freud, Sigmund, The Ego and the Id, trans, by Joan Riviere, Revised and ed, by James Strachey (New York and London: W,W, Norton and Company, 1962).

Civilization and Its Discontents, ed, by M, Masud R, Khan and trans, by James Strachey (London: The Hogarth Press and the Institute of Psycho-Analysis, 1973).

, Two Short Accounts of Psycho-Analysis, trans, And ed, by James Strachey (London: Penguin Books, 1991).

, Beyond the Pleasure Principle, trans, And ed, by James Strachey

(New York and London: W,W, Norton and Company, 1961). , The Question of Lay Analysis: An Introduction to Psychoanalysis, trans, by Nancy Procter-Gregg (London: Imago PublishingCompany, 1947).

Fry, John, Marcuse-Dilemma and Liberation: A Critical Analysis (New Jersey: Humanities Press, 1978).

Hegel, Georg Wilhelm Friedrich, The Phenomenology of Mind, trans, by J,B, Baillie Mineola (New York: Dover Publications, 2003).

Hyman, Edward, "Eros and Freedom: The Critical Psychology of Herbert Marcuse," in Marcuse: Critical Theory and the Promise of Utopia (Massachusetts: Bergin and Garve Publishers, 1988).

Katz, Barry, Herbert Marcuse and the Art of Liberation: An Intellectual Biography (London: Verso, 1982).

Kearney, Richard, Modern Movements in European Pbilosophy, Second Edition (Manchester and New York: Manchester University Press, 1994).

Lind, Peter, Marcuse and Freedom (London and Sydney: Croom Helm, 1985).

MacIntyre, Alasdair, Herbert Marcuse: An Exposition and a Polemic (New York: The Viking Press, 1970).

Marcuse, Herbert, Counterrevolution and Revolt (London: Allen Lane The Penguin Press, 1972). , Eros and Civilization: A Philosophical Inquiry into Freud (United

States of America: The Beacon Press, 1966). , The Aesthetic Dimension: Toward a Critique of Marxist Aesthetics (London: The Macmillan Press, 1979). , One-Dimensional Man (Boston: Beacon Press Boston, 1964).

Michael Lessn6off, Michael, Political Philosophers of the Twentieth Century (Oxford: Blackwell Publishers, 1999).

Schoolman, Morton, The Imaginary Witness: The Critical Theory of Herbert Marcuse (New York: The Free Press, 1980). 
Sinnerbrink, Robert, "Recognitive Freedom: Hegel and the Problem of Recognition," in Critical Horizons, 5(2004), 271-295.

Willet, Cynthia, "A Dialectic of Eros and Freedom: Beauvoir and Marcuse," in Between the Psyche and the Social: Psychoanalytic Social Theory (New York: Rowan and Littlefield Publishers, 2002).

Wolin, Richard, Heidegger's Children, Hannah Arendt, Karl Lowith, Hans Jonas, and Herbert Marcuse (Princeton and Oxford: Princeton University Press, 2001). 